\title{
Poaceae and Fabaceae of meadows of Poltava region and their protein value
}

\author{
Larysa Orlova $^{1}$, Nataliia Vlasenko ${ }^{1}$, Svitlana Gapon ${ }^{1}$, Maryna Zhuk ${ }^{1}$, \\ Marina Dyachenko-Bohun ${ }^{1}$, Nataliia Hrytsai ${ }^{2}$, Igor Grygus ${ }^{3, *}$ \\ ${ }^{1}$ Poltava V. G. Korolenko National Pedagogical University, Ukraine \\ ${ }^{2}$ Rivne State University of Humanities, Rivne, Ukraine \\ ${ }^{3}$ National University of Water and Environmental Engineering, Rivne, Ukraine \\ *corresponding author e-mail: grigus03@gmail.com
}

Received: 30 April 2021 / Accepted: 22 December 2021

\begin{abstract}
The main representatives of meadow Poaceae and Fabaceae of Poltava region are established and their ecomorphic analysis is made. 93 species of meadow Poaceae have been found in meadow phytocenoses, which are grouped into 44 genera. Among the found cereals on biomorphs are dominated by perennials (73.0\%), on climamorphs among them approximately the same number of cryptophytes and hemicryptophytes, consideration of hygromorphs of the family indicates the predominance of mesophytic plants (56.0\%), the bulk of species by tropomorphs belongs to mesotrophic (46.0\%), viewing heliomorphs of identified family members indicates their photophobia.

71 species of Fabaceae belonging to 16 genera were found in the meadows. According to biomorphs, most of the identified species are perennials (73.0\%). According to ecomorphs, mesophilic, light-loving species, which love soils of medium richness (more than half of all identified species), predominate among the studied species.

The consequences of studying the protein in meadow Poaceae and Fabaceae of Poltava region are given. The total protein accumulation in the species studied by us was in the range of $2.5-25.8 \%$. The average values for families are given and specific quantitative indicators of separate genera and species are given.

The division of the studied species into three groups according to the content of the indicator is proposed: with low (up to 6.9\%), medium (7.0-13.0\%) and high (more than 13.0\%) number. The studied species were analyzed on a scale of protein content (from 0 to 20 points). According to the given score, the studied cereals are in the group of species with low and medium content, and legumes - medium and high.

In the dynamics of protein content during the phases of the growing season you can see a certain trend. Maximum protein is accumulated by representatives at earlier stages of ontogenesis.

Analysis of the indicator, depending on their relationship to the biomorph showed some patterns. Thus, annual species, on average, contain an indicator at the level of the second group, and perennial - all three groups. Two-year-olds most often have protein at the level of the third group. This is understandable because they need a lot of nutrients for overwintering and active flowering and fruit formation next year.

Moisture conditions also affect protein accumulation. Thus, the studied xerophilous Poaceae according to our research have $9.2 \pm 0.4 \%$, mesophilic $-8.2 \pm 1.2 \%$. Proven value biomorfy to quantify protein content. It is shown that the concentration parameter affecting growing conditions, including moisture.
\end{abstract}

Keywords: meadow phytocenoses, biodiversity, ecomorphic analysis, phenological phases, protein content, Forest-Steppe zone, Left-Bank Ukraine. 


\section{Introduction}

Meadow lands are very valuable in terms of resource biogeocenosis. They are a source of different in nature useful plants. The leading role in this regard is played by fodder, medicinal, honey and other representatives of the flora, which are definitely part of such phytocenoses (Bogdanov, 2005; Chytry, 2007; Kuzemko, 2011; Orlova, 2011; Yakubenko \& Grigora, 2003).

The content of organic and mineral substances that reflect the nutritional value of feed depends on the phenological phase of growth and development of plants. Perennial herbs are most nutritious in the early stages of the growing season, because during this period they contain not only complete protein, vitamins, but in small quantities and more animalfriendly fiber, where there is little lignin, so it is well digested (Kotyash \& Panahid, 2010). The ratio of mineral elements in plant mass and feed is important and depends on the intensity of biological absorption of chemical elements from soils, which is determined by environmental factors, plant condition and species characteristics of grasslands (Grygus et al., 2018a; Prorochenko \& Demidas, 2016).

Creating a stable fodder base for livestock over time does not lose its sharpness and is impossible without high-energy and protein feeds, which are perennial representatives of legumes and cereals, both natural and sown onions (Moisienko, 2011).

Cereals and legumes are used to create highly productive grasses. Cereal perennial grasses provide the main part of the forage yield, in particular with sufficient moisture in the Forest-Steppe zone. It has been established that forages of cereals and legumes contain up to $30 \%$ of fiber, and its content depends on the botanical composition, fertilizer and mowing time (Karbivska, 2020; Panahid et al., 2019). One of the most promising areas of intensification of onion growing in the world is the creation of sown grasslands with high legume content. Partial replacement of mineral nitrogen with symbiotic is an important reserve for reducing energy consumption, which often accounts for half of its total costs in intensive grasslands (Petrichenko \& Kurgak, 2013).

For the best use of onions as hayfields and pastures and for their highest yield, it is necessary to have accurate information about the main representatives of the flora growing there, their chemical composition, nutrients. This primarily applies to species of the families Poaceae and Fabaceae, which form the basis of such grasses. This will increase the yield and profitability of both natural and sown meadows. Each species of meadow and other plants is characterized by a specific, unique set of chemicals. It was compiled and selected for many generations. The chemical composition of plants is determined by many factors. First of all, these are individual features: species specificity, phase of development, period of ontogenesis, etc. However, it is directly dependent on growth conditions: soil, climatic, and other factors (Grygus et al., 2018b; Kurgak, 2010; Travleev et al., 2004; Jena, 1994; Kuzemko, 2008).

Chemical analysis of feeds is considered a necessary condition for assessing their nutritional value, although its results are the first step in such an assessment. As you know, the nutritional value of feed can not be expressed by one indicator, it must be comprehensive. It is believed that the more protein, carbohydrates, fats, etc. contained in the feed, the more nutritious it is, and vice versa. In the system of modern comprehensive assessment of feed nutrition, a special role belongs to protein (Polishchuk \& Bulavkina, 2011). This substance is of paramount importance in animal nutrition because it cannot be replaced by others. Based on this, the main purpose of this study was to identify the main representatives of the families Poaceae and Fabacea, their ecological analysis and the establishment of protein value in the meadows of Poltava region.

The study of meadow phytocenoses of the Left-Bank Forest-Steppe of Ukraine according to literature sources is not enough (Grygus et al., 2019; Orlova et al., 2018), because most often they are fragmentary and do not give a complete picture of biomorphological, ecological-coenotic, chemical composition of meadow flora at the present stage. That is why for the first time at the present stage, comprehensive research was conducted in the meadows of Poltava region to determine the quantitative and qualitative composition of meadows, in particular, families Poaceae and Fabacea, clarified their coenomorphic composition, saturation of major bioand ecomorphs, determine the nutritional and energy value of meadow representatives. In this aspect, theoretical and biological research and systematic ecological assessment of meadow biocenoses and discussion of their effective use of nature, which meets the requirements of sustainable development, are especially relevant.

\section{Materials and methods of research}

The work was performed within the scientific theme of the Department of Botany, Ecology and Methods of Teaching Biology of Poltava National Pedagogical University named after V.G. Korolenko "Structural and functional features of natural and artificial phytocenoses of the Left Bank Forest-Steppe of Ukraine" (state registration number 0116U002582). The research was conducted on the basis of laboratories of the Faculty of Natural Sciences of PNPU named after V.G. Korolenko. Scientists, students and masters of the Faculty of Natural Sciences of PNPU named after V.G. Korolenko. 
The basis is the materials of research conducted during 1996-2020. The study of family biodiversity was carried out by conventional botanical methods. The following methods were used in the study: field, laboratory, statistical, comparative and computational. The geobotanical survey used descriptions of the trial plots, and the ecomorphic analysis of the species composition was carried out taking into account the ecobiomorphs O.L. Belgard (Andrusevych \& Zadorozhnaya, 2019; Goncharenko, 2000; Grigora \& Solomakha, 2005; Gritsayenko et al., 2003).

The study of nitrogen content in the aboveground mass was performed by the Kjeldahl method, in particular, the protein was calculated by converting the nitrogen content by a factor of 6.25 (Kushnir et al., 2017). Crude protein is defined as the amount of total nitrogen, which is determined in the sample by one of the analytical methods, multiplied by the appropriate factor. In the production of feed or proteinvitamin-mineral supplements to convert total nitrogen into protein, manufacturers always use a factor of 6.25. On average, it is assumed that the nitrogen content in the protein is $16 \%$. Hence, the conversion factor of nitrogen to protein 6.25 (100: 16). The photometric classical Kjeldahl method is included in the state standard for the determination of total nitrogen/crude protein. The method is based on the decomposition of organic substances of the test sample with concentrated sulfuric acid with the formation of ammonium salts and subsequent photometric determination of nitrogen in the form of colored indophenolic compound formed in alkaline medium by interaction with sodium salicylate and hypochlorite and has a maximum light absorption. The Kjeldahl method remains the generally accepted method for determining protein and is most often used as a reference for calibrating other methods for determining the mass fraction of protein and devices for rapid analysis. This method is included in state standards as arbitration and is widely used in both laboratories and feed mills (DSTU ISO 5983: 2003).

The research results were processed by B.A. Dospekhov and using the application program "Statistica" (Yeshchenko et al., 2005, Fundamentals of scientific research in agronomy; Tsarenko et al., 2000).

\section{Results and discussion}

According to the literature and our own observations, we found 118 species of plants of the Poaceae family in the territory of Poltava region. The family members are divided into 52 families. That is, out of 99 genera of Ukraine in the studied region there are slightly more than half $(52.5 \%)$ (Orlova, 2008b). 93 species have been found in meadow phytocenoses, which are grouped into 44 genera. The genera Poa L. and Festuca L. had the highest species saturation, both in the flora of Ukraine and in Poltava region (in general and in meadows). Representatives of the genera Agrostis L., Alopecurus L. were also quite numerous in the places of observation Bromopsis Fourr, Cripsis Aist., Elitrigia L. Digitaria Hall., Gliceria R. Br., Koeleria Pers., Melika L.

Among the found cereals by biomorphs, perennials predominate $(73.0 \%)$, annuals slightly (23.0\%). According to climamorphs, approximately the same number of cryptophytes and hemicryptophytes are among them. In total, they make up $2 / 3$ of the total number of species. Consideration of hygromorphs of the family indicates the predominance of mesophytic plants $(56.0 \%)$. The majority of species are mesotrophic (46.0\%). Also, a significant proportion of plants grow on swampy sandy soils, poor in available nutrients (38.0\%). Examination of heliomorphs of the identified family members indicates their light-loving.

Plants of this family play a very important role in compiling meadow phytocenoses of Poltava region. Due to their environmental ability, these representatives play an exceptional role in the accumulation of organic matter in the soil, in the formation of turf. Most often, they are either background plants or dominate along with other species. They also have a prominent place in the formation of the crop of hayfields and pastures, because they make up 50-70\% of the aboveground mass (Orlova, 2008a).

Representatives of the family Fabaceae are also an integral part of meadow grasslands of Poltava region (Orlova, 2004). In meadows, they are background plants and give 5-10\% (average) of the mass of the crop. Representatives of this group are rarely found in plant groups as dominants or subdominants. Legume components in meadows are variable and their participation in the formation of the phytocenosis varies greatly depending on weather conditions or due to the short life cycle. But this variability is not observed in all species and not under all circumstances. The reduction of their participation in grasslands or even their complete disappearance does not indicate the replacement of this phytocenosis with others, but only indicates its temporary changes.

71 species of Fabaceae belonging to 16 genera were found in the meadows. The most numerous were the genera Astragalus L. (13 species), Trifolium L. (11 species), Viccia L. (9 species).

According to biomorphs, most of the identified species are perennials $(73.0 \%)$. Their number may vary over the years, and sometimes they may disappear altogether. At the same time they retain underground organs or seeds and under favorable conditions restore their dominance. Onetwo-year-old legumes form a large number of viable seeds, which even in conditions of almost complete turfing can give numerous offspring in some years. On disturbed soils, their number can be quite significant. 
According to ecomorphs, mesophilic, light-loving species that love soils of medium richness (more than half of all identified species) predominate among the studied species.

One of the important criteria for evaluating meadow pasture grass and hay is the protein content, which belongs to the conventional units. Its amount is calculated based on the determination of nitrogen content. Fodder qualities of plant products on the content of crude protein are evaluated on a 20 -point scale: for the amount of $15 \%$ or more -20 points; $14.9-12.7 \%$ - 16 points; $12.6-11.7 \%-12$ points; $11.6-9.9 \%$ - 9 points; $9.8-8.3 \%-6$ points; $8.2-6.1 \%-3$ points; $6 \%$ and less -0 points (Orlova, 2011).

The content of crude protein in forage grasses can vary significantly depending on species and varietal characteristics, soil and climatic factors, fertilizers, mowing. Often in the hay of the second slope of crude protein may be more than in the hay of the first.

The total protein accumulation in the species studied by us was in the range of $2.5-25.8 \%$. The studied species by protein content are divided into low (up to 6.9\%), medium (7.0-13.0\%) and high (more than $13.0 \%$ ) quantities. The average content of the indicator for the main economic groups allocated to meadows was as follows: species of the family Poaceae $8.9 \pm 0.8 \%$, Fabaceae $14.0 \pm 0.9 \%$, weeds $7.2 \pm 0.3 \%$ (Orlova, 2007; Orlova et al., 1997). The obtained indicators are influenced by the systematic composition of the studied plants, weather conditions of today, in particular much wider temperature indicators and less moisture in recent decades both in Ukraine and in Poltava region and others.

On the example of Poa pratensis L. we analyzed the chemical composition of the plant in the earing-flowering phase (Orlova, 2009b), including protein. The results are listed in Table 1, where, along with our results for different species, data from other regions are given (Orlova, 2011). Poa pratensis protein contains more than the authors suggest in the Donbass.

Alopecurus pratensis L. (Table 1) accumulates a small amount of protein (Orlova, 2009a), compared with other cereals we studied and the results provided by researchers from other regions.

Dactylis glomerata L. (Table 1) is one of the best forage herbaceous meadow plants and is higher in nutritional value than meadow thyme, fireweed and buckthorn (Orlova, 2011). According to our data (average over several years from different places of growth) in the aboveground mass of the plant contains a fairly large amount of protein. The nitrogen content in the plant in terms of protein is much higher than the results of studies by other scientists.

According to the given score, the studied cereals are in different groups by the amount of protein: representatives with 16 points (Poa pratensis), with 9 points (Dactylis glomerata) and 3 points (Alopecurus pratensis). According to our gradation, they were part of a group of species with low and medium content.

Table 1. Protein content in meadow cereals fodder plants (\% on dry matter)

\begin{tabular}{|l|c|c|c|}
\hline $\begin{array}{c}\text { Growth conditions } \\
\text { in region }\end{array}$ & $\begin{array}{c}\text { Poa } \\
\text { pratensis } \mathrm{L} .\end{array}$ & $\begin{array}{c}\text { Alopecurus } \\
\text { pratensis } \mathrm{L} .\end{array}$ & $\begin{array}{c}\text { Dactylis } \\
\text { glomerata } \mathrm{L} .\end{array}$ \\
\hline Poltava & $12.8 \pm 0.3$ & $6.9 \pm 0.1$ & $10.0 \pm 0.9$ \\
\hline Donbass & 10.6 & 11.4 & 8.5 \\
\hline Forest-steppe of Ukraine & & 15.3 & \\
\hline
\end{tabular}

Leguminous components of grasses are an indispensable source of feed protein. Today they are the main representatives of the flora to solve the problem of protein deficiency in feed and meadow feed production (Kvitko et al., 2012).

Among the legumes Vicia cracca L. It is one of the best representatives of the family and high-protein plants, and the presence of protein in the plant up to $30.0 \%$. According to certain indicators of chemical composition, the species is second only to Trifolium L. and Medicago L. Our results indicate the average values of the indicator in the studied species (Table 2). Fluctuations over the four years of the study were also significant. Its concentration in the studied population gradually decreased. In the last year of study, it was almost twice less than in the first year of the study. However, in the second year of the study, the protein was slightly higher than in the first year. But the maximum values in our conditions are slightly higher than those given by other authors (Orlova, 2006).

Table 2. Protein content in meadow legumes (\% on dry matter)

\begin{tabular}{|l|c|c|c|c|}
\hline \multicolumn{1}{|c|}{$\begin{array}{c}\text { Growth } \\
\text { conditions }\end{array}$} & $\begin{array}{c}\text { Vicia } \\
\text { cracca } \\
\text { L. }\end{array}$ & $\begin{array}{c}\text { Melilotus } \\
\text { albus } \\
\text { Medik. }\end{array}$ & $\begin{array}{c}\text { Melilotus } \\
\text { officinalis } \\
\text { (L.) Pall. }\end{array}$ & $\begin{array}{c}\text { Lotus } \\
\text { ucrainicus } \\
\text { Klokov. }\end{array}$ \\
\hline Poltava region & $17.7 \pm 2.6$ & $18.7 \pm 2.7$ & $16.2 \pm 3.2$ & $13.9 \pm 0.2$ \\
\hline Kharkiv region & 18.5 & 19.4 & 21.4 & 24.5 \\
\hline Donbass & & 28.7 & 16.2 & \\
\hline Polissya & & 17.0 & 18.4 & 15.7 \\
\hline Crimea & & & & 24.5 \\
\hline $\begin{array}{l}\text { Forest-steppe of } \\
\text { Ukraine }\end{array}$ & & & & \\
\hline
\end{tabular}

Comparison of the chemical composition of the aboveground part of the two species of Melilotus highlighted the following picture (Table 2). Protein contains an average amount, similar to the conditions of Polissya or Donbass, depending on the species. Protein content in Melilotus albus Medik. higher than in M. officinalis (L.) Pall. (Orlova, 2008b).

Chemical analysis of the aboveground part of Lotus ucrainicus Klok. was performed. (Table 2) in the phase of 
budding - flowering, found that even in the Poltava region varies between 13.9-16.9\%. When compared to other regions, there are also differences. At the same time, the results were similar in the results of studies of the species in the ForestSteppe of Ukraine (Orlova, 2007).

We found out the chemical composition of 6 species of Trifolium in the budding-flowering phase (Table 3). The best values of the studied indicators were found in T. repens, T. alpestre and T. montanum (Orlova, 2001).

Table 3. Protein content of species of the genus Trifolium (\% on dry matter)

\begin{tabular}{|c|c|c|c|c|c|c|}
\hline \multirow{2}{*}{$\begin{array}{c}\text { View } \\
\begin{array}{c}\text { Indica- } \\
\text { tor }\end{array}\end{array}$} & $\begin{array}{c}\text { T. monta- } \\
\text { num L. }\end{array}$ & $\begin{array}{c}\text { T. alpestre } \\
\text { L. }\end{array}$ & $\begin{array}{c}\text { T. medium } \\
\text { L. }\end{array}$ & $\begin{array}{c}\text { T. repens } \\
\text { L. }\end{array}$ & $\begin{array}{c}\text { T. pratense } \\
\text { L. }\end{array}$ & $\begin{array}{c}\text { T. sativum } \\
\text { (Schreb.) } \\
\text { Crome }\end{array}$ \\
\hline
\end{tabular}

\begin{tabular}{l|c|c|c|c|c|c|}
\hline Protein & $12.8 \pm 0.5$ & $12.3 \pm 0.4$ & $9.5 \pm 0.06$ & $12.9 \pm 0.03$ & $10.2 \pm 0.01$ & $7.4 \pm 0.02$ \\
\hline
\end{tabular}

Analysis of the studied legumes on the protein content on a scale allows them to be classified into different groups: with 20 points (Vicia cracca, Melilotus albus, Melilotus officinalis), with 16 points (Lotus ucrainicus), and among the species Trifolium - from 16 to 3 points. On this scale, Trifolium species were in the middle group, and the rest - with a high content of the indicator.

In the dynamics of protein content during the phases of the growing season you can see a certain trend. Maximum protein is accumulated by representatives at earlier stages of ontogenesis (Fig. 1). Literature data also show (Orlova, 2011) that the highest protein content is found in cereals at a young age, in particular the tillering phase, and then decreases until the death of plants.

Analysis of the indicator, depending on their relationship to the biomorph (according to O.L. Belgard) (Orlova, 2011), showed some patterns. Thus, annual species, on average, contain an indicator at the level of the second group, and perennial - all three groups. Two-year-olds most often have protein at the level of the third group. This is understandable because they need a lot of nutrients for overwintering and active flowering and fruit formation next year.

Call conditions also affect protein accumulation. Thus, the studied xerophilous Poaceae according to our research have $9.2 \pm 0.4 \%$, mesophilic $-8.2 \pm 1.2 \%$. Hygrophilic members of the family accumulate $9.6 \%$ of protein. These results appear to those who are the first to finish everything that ends, and plan to change the beginning of mid-June, after which they group the group and almost dry up. Others - develop slowly, later begin the first and after fruiting coarse, but do not dry out so quickly. Others bloom later than others, but at this time are very rude. Therefore, the times are widely used before the earing phase.

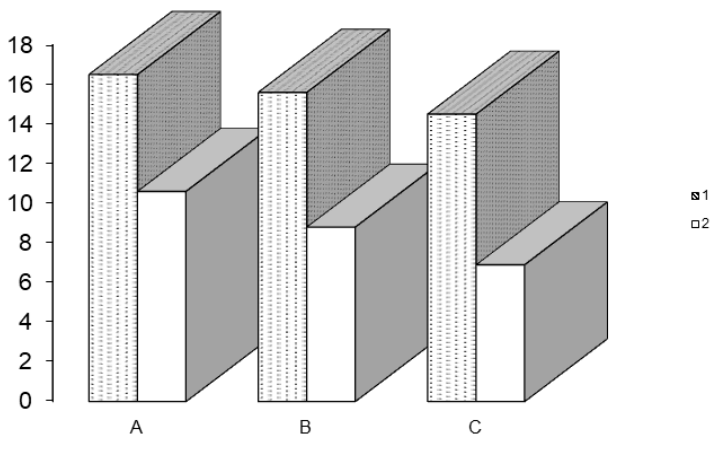

Figure 1. Dynamics of protein content of Poa pratensis L. (1) and Festuca rupicola Heuff. (2), \%: A - earing phase, B - flowering, C - the beginning of fruiting

\section{Conclusions}

In the meadow phytocenoses of Poltava region we found 93 species of Poaceae, which are grouped into 44 genera and 71 species of Fabaceae, which belong to 16 genera. According to biomorphs, most of the identified species are perennials; according to ecomorphs, mesophilic, mesotrophic, and heliophilic species predominate among the studied species. Representatives of the Poaceae family had an average protein of $8.9 \pm 0.8 \%$, and Fabaceae $14.0 \pm 0.9 \%$. Among the species studied by us in both families were representatives with different levels of protein accumulation: with low (up to 6.9\%), medium (7.0-13.0\%) and high (more than 13.0\%) content. The studied species were analyzed on a scale of protein content (from 0 to 20 points). Its number is significantly influenced by the phenological phase, biomorph and growth conditions. The obtained data show that the studied representatives of the flora are the main components of meadow biogeocenoses, which functionally connect all their components, determine their balance and productivity.

Prospects for further research. Further monitoring studies of both the species composition of meadow phytocenoses and their chemical composition and productivity for the creation and use of meadow grasslands of Poltava region are planned. The research results will be used to assess the current state of meadow lands in the region in the development and implementation of production tasks of the agro-industrial and forestry complex of Poltava region. Such studies will be especially valuable when they are conducted in specific regions. This will allow more efficient use of meadow phytocenoses and further choice of ways to improve the level of anthropogenic load. Meadow land optimization is an integral part of the concept of sustainable development as a mandatory and effective element of public policy. 


\section{References}

Andrusevych K. \& Zadorozhnaya, G., 2019, Diversity, dynamics and ecological analysis of flora of reclaimed soil. Folia Oecologica 46(2): 153-163.

Bogdanov V.L., 2005, Formation of stable meadow phytocenoses in disturbed ecosystems, (dissertation). SPb, 343 pp.

Chytry M. (ed.), 2007, Vegetace Ceske republiky. 1. Travinna a ker ckova vegetace [Vegetation of Czech Republic. 1. Grassland and heathland vegetation]. Academia, Praha, $528 \mathrm{pp}$.

Goncharenko I.V., 2000, Meadow vegetation of the north-eastern part of the Left-Bank Forest-Steppe of Ukraine. Ukr. botan. magazine 57(6): 669-675.

Grigora I.M. \& Solomakha V.A., 2005, Vegetation of Ukraine (ecological-coenotic, floristic and geographical essay). Phytosocial center, Kiev, 452 pp.

Gritsayenko Z.M., Gritsayenko A.O., \& Karpenko V.P., 2003. Methods of biological and agrochemical studies of plants and soils. Nichlava, Kiev, 320 pp.

Grygus I., Kaskyv M., Zukow W., 2018a, Evaluation of ecological and genetic condition of Rivne city for Micronucleus Test. Ecological Questions 29(1): 119-127.

Grygus, I., Lyko, S., Stasiuk, M., Zubkovych, I., \& Zukow, W., 2018b, Risks posed by Heracleum sosnowskyi Manden in the Rivne region. Ecological Questions 29(4): 35-42. doi: http://dx.doi.org/10.12775/EQ.2018.032

Grygus I., Zukow W., Kushniruk Y., Korotun S., 2019, Medical-geographical and radiological aspects of the system "environment - population health". Ecological Questions 30(3): 1-15. doi: http://dx.doi.org/ 10.12775/EQ.2019.019

Jena G.B., 1994, Mutagenecity of an organophosphate insecticide acephate - an organophosphate in vivo study in chicks. Mutagenesis (9): 319-324.

Karbivska U.M., 2020, The content of organic matter in the feed of cereal grass in the Carpathians. Bulletin of the Poltava State Agrarian Academy (2): 19-25. doi: https:// doi.org/10.31210/visnyk2020.02.02

Kotyash U.O. \& Panahid G.Ya., 2010, Chemical composition of forage of meadow grasses under different fertilization systems and mowing dates. Foothill and mountain agriculture and animal husbandry 52(1): 50-54.

Kurgak V.G., 2010, Meadow agrophytocenoses. DIA, Kyiv, $374 \mathrm{pp}$.

Kushnir G.V., Levitsky T.R., Rivak G.P., Kurilas L.V., Vilkha O.M. \& Fedor G.Yu., 2017, Characteristics of modern methods for determination of crude protein in feed and vegetable raw materials. NV LNU of Veterinary Medicine and Biotechnology 19(82): 97-100.
Kuzemko A.A., 2008, Wild food plants in the meadow community is of Ukraine. In: Proceedings of the Conference: Wild plants of the dining room remember the potential of nature. September 13, 2007, Przemyśl-Bolestraszyce, p. $240-251$.

Kuzemko A.A., 2011, The role of altiude, latiude and longitude in the distribution of the meadow vegetation in the flodplains of the Northern Ukraine. Ann. Bot. (Roma) 2(1): 73-80.

Kvitko G.P., Tkachuk N.Ya. \& Hetman N.Ya., 2012, Perennial legumes are the basis of natural intensification of fodder production and soil improvement in the Forest-Steppe of Ukraine. Feed and Feed Production 73: 113-117.

Moisienko V.V., 2011, Scientific substantiation of ways to increase forage productivity and longevity of perennial grasses. Bulletin of ZhNAEU 1(1): 35-57.

Orlova L.D., 2001, Study of fodder value of Trifolium meadows of Poltava region. Bulletin of Dnipropetrovsk University. Biology, Ecology 9(2): 165-168.

Orlova L.D., 2004, Participation of members of the legume family (Fabaceae Lindl.) in the creation of meadow grasslands of Poltava region, [in:] Collection of works of Poltava State Pedagogical University named after V.G. Korolenko, Poltava 4(37): 14-21.

Orlova L.D., 2006, Bioecological and phytochemical characteristics of Vicia cracca L. in Poltava region. In: Collection of works of Poltava State Pedagogical University named after V.G. Korolenko, Poltava 5(52): 52-56.

Orlova L.D., 2007, Bioecological features and chemical composition of Lotus ukrainicus Klok. on the meadows of Poltava region, [in:] Collection of works of PDPU named after V.G. Korolenko, Poltava 6(58): 2-27.

Orlova L.D., 2008a, Chemical composition of Melilotus (Fabaceae) of Poltava region. Bulletin of Dnipropetrovsk University. Biology, Ecology 16(2): 122-126.

Orlova L.D., 2008b, Systematic analysis and bioecological features of the Poaceae Barnhart family of Poltava region, [in:] Collection of Sciences. etc. Issues of steppe forestry and forest land reclamation 37: 72-76.

Orlova L.D., 2009a, Bioecology and chemical composition of Alopecurus pratensis L. in the meadows of Poltava region. In: Collection of scientific. tr. Industrial Botany 9: 191-193.

Orlova L.D., 2009b, Bioecology and productivity of Poa pratensis in the meadows of Poltava region, [in:] Collection of works of PDPU V. G. Korolenko, Poltava 1: 17-21.

Orlova L.D., 2011, Bioecological features of meadow phytocenoses of the Left-Bank Forest-Steppe of Ukraine (productivity and rational use). PNPU named after V. G. Korolenko. Poltava, 278 pp. 
Orlova L.D., Roman V.V. \& Trotsky M.Ya., 1997, Phytochemical study of wild forage plants of the legume family near Poltava. In: Coll. articles. Fourth Karyshin readings: All-Ukrainian. interuniversity. Scientific method conference on the problems of natural sciences, dedicated to the memory of A.P. Karishina, Poltava, p. 29-33.

Orlova L.D., Vlasenko N.O. \& Koval O.V., 2018, Modern researches of meadow phytocenoses of Poltava region. Bulletin of problems of biology and medicine 4(1): 25-28. doi:10.5281/zenodo.1318173

Panahid G.Ya., Konik G.S. \& Kotyash U.O., 2019, The content of organic substances in the feed of herbaceous-cereal meadow agrophytocenosis of long use. Foothill and mountain agriculture and animal husbandry 65: 103-114. doi: https://www.doi.org/10.32636/01308521. 2019-(65)-10

Petrichenko V.F. \& Kurgak V.G., 2013, Cultural hayfields and pastures of Ukraine. Agrarian Science, Kyiv, 432 pp.

Polishchuk A.A. \& Bulavkina T.P., 2011, The relationship between the digestibility of diets with protein supplements of different nature and their chemical compo- sition. Bulletin of the Poltava State Agrarian Academy 4: 64-67.

Prorochenko S.S. \& Demidas H.I., 2016, Accumulation of nitrogen nitrogen in feed depending on fertilizers and species composition of legumes. Vinnytsia, p. 82-86.

Travleev A.P., Belova N.A. \& Travleev L.P., 2004, Typology of steppe forests and forest soil formation (for the 50th anniversary of the DNU Comprehensive Expedition). Issues of steppe forestry and forest land reclamation 8(33): 4-13.

Tsarenko O.M., Zlobin Y.A., Sklyar V.G. \& Panchenko S.M., 2000, Computer methods in agriculture and biology: textbook. Manual. University book, Sumy, 203 pp.

Yakubenko B.E. \& Grigora I.M., 2003, Current state and changes of natural forage lands in the aspect of plant production technology. Scientific support of sustainable development of agriculture in the Forest-Steppe of Ukraine. Monograph in 2 volumes. Cabinet of Ministers of Ukraine. NAU. T. 2. Alefa, Kyiv, p. 555-571.

Yeshchenko B.O., Kopitko P.G., Opryshko V.P. \& others, 2005, Fundamentals of scientific research in agronomy: textbook. Action, Kyiv, 288 pp. 